\title{
Dietary lipid level affects growth performance and nutrient utilisation of Senegalese sole (Solea senegalensis) juveniles
}

\author{
Pedro Borges ${ }^{1,2}$, Beatriz Oliveira ${ }^{2},{\text { Susana } \text { Casal }^{2} \text {, Jorge Dias }}^{3}$, Luis Conceição ${ }^{3}$ and Luísa M. P. Valente ${ }^{1 *}$ \\ ${ }^{1}$ CIMAR/CIIMAR, Centro Interdisciplinar de Investigação Marinha e Ambiental and ICBAS, Instituto de Ciências Biomédicas de \\ Abel Salazar, Universidade do Porto, Rua dos Bragas, 177, 4050-123 Porto, Portugal \\ ${ }^{2}$ REQUIMTE, Serviço de Bromatologia, Faculdade de Farmácia da Universidade do Porto, R. Aníbal Cunha 164, 4050-047 Porto, \\ Portugal \\ ${ }^{3}$ CIMAR/CCMAR, Centro de Ciências do Mar do Algarve, Universidade do Algarve, Campus de Gambelas, 8005-139 Faro, \\ Portugal
}

(Received 19 January 2009 - Revised 9 March 2009 - Accepted 12 March 2009 - First published online 27 April 2009)

Over the last few years, several aspects of Senegalese sole (Solea senegalensis) culture have been developed and optimised but the dietary lipid level for optimal growth has never been determined. Hence, five isonitrogenous diets (56\% dietary protein) with increasing dietary lipid levels $(4,8,12,16$ and $20 \% \mathrm{DM})$ were fed to satiation to triplicate groups of twenty fish (mean initial weight $10 \mathrm{~g})$. Fifteen tanks were randomly assigned one of the five diets. Feed was distributed using automatic feeders, and fish were fed over a 16-week period. At the end of the experiment the fish fed on diets containing the two lowest dietary lipid levels (4 and $8 \%$ ) showed a 3-fold body-weight increase with a significantly higher daily growth index than fish fed higher lipid levels $(1 \cdot 2$ v. 0.8$)$. Moreover, these fish displayed a significantly lower dry feed intake (12 g/kg per d) and feed conversion ratio (1.0) compared with fish fed higher lipids levels (16-19 g/kg per d; feed conversion ratio 2.0). Low dietary lipid levels $(<12 \%)$ significantly improved nutrient retention and gain and hence growth, without major effects on whole-body composition. Despite the slight alteration in $n$-3 PUFA muscle content in the fish fed low-fat-diets, this fish fed low dietary lipid still remains a rich $n$-3 PUFA product and generally maintained its nutritional value. These results evidenced a low lipid tolerance of Senegalese sole juveniles and suggest a maximal dietary inclusion level of $8 \%$ lipids for both optimal growth and nutrient utilisation without compromising flesh quality.

Lipid nutrition: Flatfish: Dietary lipid tolerance: Protein-sparing effect

The aquaculture industry has expanded in Europe over the last decades, but few marine fish species have contributed to this growth. The successful development of Southern European aquaculture has resulted in increased production of gilthead seabream (Sparus aurata), sea bass (Dicentrarchus labrax) and turbot (Psetta maxima), leading to market saturation and reduced prices. For these reasons, great efforts have recently been devoted to find new candidate species, to improve diversity and to ensure sustainable development of the industry.

Senegalese sole (Solea senegalensis) is a promising flatfish species for marine farming, especially due to its high market value. Over the last few years significant advances have been accomplished on Senegalese sole weaning techniques and larvae feeding ${ }^{(1-3)}$. However, little is known about the nutritional needs of this flatfish species during its juvenile stage $^{(4,5)}$. The protein requirement for maximum protein accretion in Senegalese sole has been estimated at $600 \mathrm{~g} / \mathrm{kg}$ $\operatorname{diet}^{(5)}$, but, so far, no studies concerning the optimal dietary lipid level have been carried out.

Dietary formulations in aquaculture tend to increase lipid content as a non-protein source for enhancing growth and sparing protein, and for reducing organic matter and $\mathrm{N}$ losses $^{(6-10)}$. Nevertheless, in flatfish species positive results on protein sparing are limited and controversial. High dietary lipids enhanced growth and protein utilisation in plaice (Pleuronectes platessa $)^{(11)}$, whereas no beneficial effects were reported in halibut (Hippoglossus hippoglossus) ${ }^{(12-17)}$ and Senegalese $\operatorname{sole}^{(4)}$. Moreover, turbot (Psetta maxima and Scophtalmus maximus) was negatively affected by dietary lipids ${ }^{(17,18)}$.

The quantity, quality and body fat stores vary widely among fish species and mainly depend on dietary factors. In salmonids, fat deposition occurs mainly in the viscera and to a lesser extent in the muscle ${ }^{(19)}$, whereas in flatfish species, such as turbot, the marginal body parts and subdermal fat constitute the most important lipid deposition sites ${ }^{(18,20)}$. Increasing the dietary lipid levels can alter body composition and slaughter quality, particularly through an increase in lipid deposition $^{(11-12,16,19)}$ affecting flesh organoleptic properties and final consumer's acceptance.

The aim of the present study was to determine the optimal dietary lipid level that can simultaneously improve growth

Abbreviations: HF, high-fat; LF, low fat.

* Corresponding author: Dr Luísa M. P. Valente, fax +351 2234018 38, email lvalente@icbas.up.pt 
without compromising final flesh quality in Senegalese sole juveniles. The effects of increasing dietary lipid levels (4 to $20 \%$ ) on growth, feed efficiency, whole-body composition, nutrient and energy retention and tissue lipid deposition were evaluated in Senegalese sole juveniles over a 16-week period.

\section{Materials and methods}

\section{Experimental diets}

Five isonitrogenous (56\% DM) experimental diets were formulated to contain increasing lipid levels $(4,8,12,16$ and $20 \%$ DM; L4, L8, L12, L16 and L20, respectively). The dietary protein fraction was achieved by means of a variable blend of practical ingredients such as fishmeal, soyabean meal, maize gluten and wheat gluten, whereas increasing lipid levels were obtained by increasing fish oil inclusion.
Ingredients and proximate composition are presented in Table 1. Ingredients were finely ground, mixed and pelleted dry without steaming using a laboratory pelleting machine (C-300 model; California Pellet Mill, San Francisco, CA, USA) with a $2.0 \mathrm{~mm}$ die. The diets were dried at $37^{\circ} \mathrm{C}$ for $24 \mathrm{~h}$ and stored in a refrigerator $\left(4 \pm 1^{\circ} \mathrm{C}\right)$ until use.

\section{Growth trial}

Experiments were directed by trained scientists (following FELASA category $\mathrm{C}$ recommendations) and were conducted according to the European Economic Community animal experimentation guidelines directive of 24 November 1986 (86/609/EEC). The study was performed at the experimental facilities of CIIMAR (Porto, Portugal), with Senegalese sole (Solea senegalensis) juveniles supplied from a commercial fish farm (Alrogal, La Coruña, Spain). After arrival at the

Table 1. Ingredients, proximate composition and fatty acid composition ( $\mathrm{g} / 100 \mathrm{~g}$ fatty acids) of the experimental diets with different levels of dietary lipids

\begin{tabular}{|c|c|c|c|c|c|}
\hline & \multicolumn{5}{|c|}{ Dietary treatments (\%) } \\
\hline & L4 & L8 & L12 & L16 & L20 \\
\hline \multicolumn{6}{|l|}{ Ingredients (\%) } \\
\hline Fishmeal LT & 37 & 37 & 37 & 37 & 37 \\
\hline CPSP G & $1 \cdot 0$ & $2 \cdot 0$ & 3.5 & 3.5 & 3.5 \\
\hline Squid meal & 5 & 5 & 5 & 5 & 5 \\
\hline Soyabean meal 48 & $16 \cdot 0$ & $16 \cdot 0$ & $14 \cdot 0$ & $13 \cdot 3$ & $9 \cdot 5$ \\
\hline Maize gluten & $12 \cdot 5$ & $12 \cdot 5$ & $12 \cdot 0$ & $12 \cdot 0$ & $9 \cdot 0$ \\
\hline Wheat meal & $23 \cdot 0$ & $18 \cdot 0$ & 14.5 & $10 \cdot 0$ & $8 \cdot 0$ \\
\hline Wheat gluten & 3.0 & 3.0 & 3.5 & 4.5 & $9 \cdot 0$ \\
\hline Gelatin & 2 & 2 & 2 & 2 & 2 \\
\hline Fish oil & 0 & $4 \cdot 0$ & $8 \cdot 0$ & $12 \cdot 2$ & $16 \cdot 5$ \\
\hline Choline chloride & 0.1 & 0.1 & 0.1 & 0.1 & $0 \cdot 1$ \\
\hline Lutavit C35 & 0.03 & 0.03 & 0.03 & 0.03 & 0.03 \\
\hline Lutavit E50 & 0.05 & 0.05 & 0.05 & 0.05 & 0.05 \\
\hline Mineral and vitamin $\operatorname{mix}^{*} \dagger$ & 0.25 & 0.25 & $0 \cdot 25$ & 0.25 & 0.25 \\
\hline Betaine & 0.07 & 0.07 & 0.07 & 0.07 & 0.07 \\
\hline \multicolumn{6}{|l|}{ Proximate composition } \\
\hline DM (\%) & $91 \cdot 30$ & $91 \cdot 70$ & $92 \cdot 20$ & 92.44 & $92 \cdot 61$ \\
\hline Ash (\% DM) & 8.48 & 8.44 & $8 \cdot 30$ & $7 \cdot 85$ & $7 \cdot 82$ \\
\hline Crude protein (\% DM) & 57.02 & $56 \cdot 06$ & $56 \cdot 82$ & 57.52 & $56 \cdot 06$ \\
\hline Crude fat (\% DM) & 4.07 & 8.40 & 13.67 & $17 \cdot 35$ & $22 \cdot 50$ \\
\hline Gross energy (kJ/g DM) & $20 \cdot 56$ & $21 \cdot 78$ & $22 \cdot 87$ & $23 \cdot 81$ & 24.58 \\
\hline \multicolumn{6}{|l|}{ Fatty acid composition } \\
\hline$\Sigma$ SFA & 24.66 & 24.06 & 23.93 & 23.09 & 23.59 \\
\hline$\Sigma$ MUFA§ & $20 \cdot 88$ & 28.59 & 33.09 & 33.41 & 33.74 \\
\hline$\Sigma$ PUFA\| & $48 \cdot 47$ & 41.96 & $37 \cdot 30$ & 37.47 & 36.42 \\
\hline$\sum n-39$ & $25 \cdot 24$ & 25.43 & $24 \cdot 81$ & 24.83 & 23.62 \\
\hline DHA:EPA & $1 \cdot 13$ & 1.15 & $1 \cdot 15$ & $1 \cdot 17$ & $1 \cdot 16$ \\
\hline EPA:ARA & $13 \cdot 12$ & $13 \cdot 70$ & 13.54 & 13.49 & $13 \cdot 19$ \\
\hline
\end{tabular}

LT, low temperature; CPSP G, fish soluble protein concentrate (hydrolysed fishmeal); ARA, arachidonic acid.

*Vitamins (per kg diet): vitamin A, $8000 \mathrm{IU}(2.4 \mathrm{mg})$; vitamin $\mathrm{D}_{3}, 1700 \mathrm{IU}(0.04 \mathrm{mg})$; vitamin $\mathrm{K}_{3}$, $10 \mathrm{mg}$; vitamin $B_{12}, 0.02 \mathrm{mg}$; vitamin $B_{1}, 8 \mathrm{mg}$; vitamin $B_{2}, 20 \mathrm{mg}$; vitamin $B_{6}, 10 \mathrm{mg}$; folic acid, $6 \mathrm{mg}$; biotin, $0.7 \mathrm{mg}$; inositol, $300 \mathrm{mg}$; nicotinic acid, $70 \mathrm{mg}$; pantothenic acid, $30 \mathrm{mg}$; vitamin E (Lutavin E50), 300 mg; vitamin C (Lutavin C35), $500 \mathrm{mg}$; betaine (Betafin S1), $500 \mathrm{mg}$.

† Minerals (per $\mathrm{kg}$ diet): $\mathrm{Mn}$ (manganese oxide), $20 \mathrm{mg}$; I (potassium iodide), $1.5 \mathrm{mg}$; Cu (copper sulfate), $5 \mathrm{mg}$; Co (cobalt sulfate), $0.1 \mathrm{mg}$; Mg (magnesium sulfate), $500 \mathrm{mg}$; Zn (zinc oxide), $30 \mathrm{mg}$; Se (sodium selenite), $0.3 \mathrm{mg}$; Fe (iron sulfate), $60 \mathrm{mg}$; $\mathrm{Ca}$ (calcium carbonate) $2.15 \mathrm{~g}$; dibasic calcium phosphate, $5 \mathrm{~g} ; \mathrm{KCl}, 1 \mathrm{~g} ; \mathrm{NaCl}, 0.4 \mathrm{~g}$.

$\ddagger \Sigma$ SFA $=$ sum of $12: 0,14: 0,15: 0,16: 0,17: 0,18: 0,20: 0,22: 0$ and $24: 0$.

$\S \Sigma$ MUFA $=$ sum of $16: 1,18: 1,20: 1$ and $22: 1$.

$\| \Sigma$ PUFA $=$ sum of $18: 2 n-6,18: 3 n-6,18: 3 n-3,20: 2 n-6,20: 3 n-3,20: 4 n-6,20: 5 n-3,22: 4 n$ $6,22: 5 n-3$ and $22: 6 n-3$

I $\Sigma n-3=$ sum of $18: 3 n-3,20: 3 n-3,20: 5 n-3,22: 5 n-3$ and $22: 6 n-3$. 
experimental unit fish were acclimatised to the new rearing facilities for 2 weeks. For each treatment, triplicate groups of twenty fish (average initial body weight 9.9 (SD 1.8) g) were distributed among fifteen fibreglass tanks $(50 \times 35 \mathrm{~cm}$; initial fish density $\left.1 \mathrm{~kg} / \mathrm{m}^{2}\right)$. Each tank was supplied with filtered, heated $\left(20 \pm 1^{\circ} \mathrm{C}\right)$ seawater $(30 \%$ ), at a flow rate of 2 litres per min. The most important physical and chemical parameters (temperature, dissolved $\mathrm{O}_{2}$, salinity, $\mathrm{pH}$ and nitrogenous compounds) were monitored during the entire trial and maintained at levels within limits recommended for marine species. Fish were exposed to an artificial photoperiod of $12 \mathrm{~h}$ light $-12 \mathrm{~h}$ dark. At the beginning and end of the experiment individual fish weights were recorded. Fish were fed by automatic feeders $24 \mathrm{~h}$ per $\mathrm{d}$. The ration offered was daily adjusted based on the feed losses in each tank. Each day, all tanks were monitored to be certain that all feed was eaten and hence, no feed lost was registered. When some uneaten food remained in the bottom of the tank, the total amount of feed distributed each day was reduced by $10 \%$, until no feed losses were recorded. When no feed losses were observed the amount of food was maintained for $4 \mathrm{~d}$ and then augmented $10 \%$ during all the experiment.

At the beginning of the experiment, a pooled sample of ten fish from the initial stock was sampled and stored at $-20^{\circ} \mathrm{C}$ for subsequent whole-body composition analysis. Liver and viscera weights were also recorded. At the end of the trial, four fish from each tank were sampled for the same purpose. Liver, viscera, dorsal muscle and skin were removed from three fish per tank, frozen in liquid $\mathrm{N}_{2}$ and stored at $-80^{\circ} \mathrm{C}$ for lipid analysis. All fish sampled were killed by a sharp blow on the head.

\section{Analytical methods}

Whole fish from each tank were ground, pooled and moisture content was determined $\left(105^{\circ} \mathrm{C}\right.$ for $\left.24 \mathrm{~h}\right)$. Fish and tissues were subsequently freeze-dried before further analysis. Feed and whole-body samples were analysed for ash by combustion in a muffle furnace (Nabertherm L9/11/B170; Bremen, Germany; $550^{\circ} \mathrm{C}$ for $6 \mathrm{~h}$ ), crude protein (Kjeldatherm TR and Vapodest 40; Gerhardt, Königswinter, Germany; microKjeldahl; $\mathrm{N} \times 6.25$ ) after acid digestion, lipid content by petroleum ether extraction using a Soxtherm Multistat/SX PC (Gerhardt, Königswinter, Germany; $40-60^{\circ} \mathrm{C}$ ) and gross energy in an adiabatic bomb calorimeter (Werke C2000; IKA, Staufen, Germany).

The extraction of total lipids in diets and tissues was carried out following the Folch et al. ${ }^{(21)}$ method with chloroformmethanol (2:1) and gravimetric determination. Liver, viscera, muscle and skin samples were analysed individually. Fatty acid methyl esters (FAME) were prepared by acid-catalysed transmethylation of total lipids using boron trifluoride methanol according to Shantha \& Ackman ${ }^{(22)}$ and were analysed in a Chrompack CP 9001 gas chromatograph (Middelburg, The Netherlands). The chromatograph was equipped with a CPSil 88 fused silica capillary column (Varian, Middelburg, The Netherlands; $50 \mathrm{~m} \times 0.25 \mathrm{~mm}$ internal diameter, film thickness $0.2 \mu \mathrm{m})$. The gas carrier used was $\mathrm{He}(120 \mathrm{kPa})$ and the thermal gradient was $5^{\circ}$ minimum at $140^{\circ} \mathrm{C}, 140^{\circ} \mathrm{C}$ to $220^{\circ} \mathrm{C}$ at $5^{\circ} \mathrm{C}$ per min and a constant temperature of $220^{\circ} \mathrm{C}$ during $15 \mathrm{~min}$. Injector and detector temperatures were $250^{\circ} \mathrm{C}$ and $270^{\circ} \mathrm{C}$, respectively. FAME were identified by comparison with standard mixtures (FAME 37 and PUFA 3; Supelco, Bellefonte, PA, USA) and data analysed using CP-Maitre software (version 2.5; Chrompack International, Bergen op Zoom, The Netherlands).

\section{Statistical analysis}

Statistical analyses followed methods outlined by Zar ${ }^{(23)}$. All data were tested for homogeneity of variances by Levene's tests, and then submitted to a one-way ANOVA with the SPSS 15.0 package (SAS Institute, Inc., Cary, NC, USA). When data did not meet the assumptions of ANOVA, the non-parametric ANOVA equivalent (Kruskal-Wallis test) was performed. When these tests showed significance, individual means were compared using Tukey or Mann-Whitney tests. Significant differences were considered when $P \leq 0 \cdot 05$.

\section{Results}

At the end of the trial (112d) average body weight showed a threefold increase for all dietary treatments. Final body weight, daily growth index, feed conversion ratio, protein efficiency ratio and nutrient intake are summarised in Table 2. High-fat (HF) diets (L12, L16 and L20) resulted in significant lower final body weight (29-33 g) when compared with the two low-fat (LF) diets (L4 and L8) (about $43 \mathrm{~g}$ ). Daily growth index varied between 0.8 and 1.2 and was significantly affected by dietary lipid levels. Fish fed the HF diets showed significantly lower growth rates compared with those fed the LF diets.

Feed conversion ratio values ranged from 1.0 (L4) to $2 \cdot 2$ (L20) with fish fed L4 and L8 showing the best feed conversion ratio and fish fed L20 being significantly less efficient than all the others. Protein efficiency ratio varied from 0.8 to 1.7 with the highest and lowest values being, again, found in fish fed the LF (L4 and L8) and L20 diets, respectively. DM intake varied significantly among treatments, increasing with the lipid dietary level, and hence affecting significantly the intake of all other nutrients. The LF diets displayed the lowest nutrient intake, whereas fish fed L20 showed an opposite trend.

At the end of the trial, whole-body moisture, energy and ash contents were similar among treatments (Table 3). However, fish fed L16 or L20 displayed significantly lower wholebody protein than fish fed L8, and higher lipid content than fish fed L4. Nutrient and energy retention (Table 3) were significantly affected by the inclusion of dietary fat. Fish fed the LF diets displayed higher protein, lipid and energy retention than those fed the HF diets. A similar trend was observed for protein, but not for lipid gain.

The hepatosomatic index varied from 0.8 to $1 \%$ and liver lipid content ranged from 8.0 to $10 \cdot 1 \%$. The hepatosomatic index was significantly higher in fish fed L16 than in those fed the L8 and L12 diets. The viscerosomatic index varied from 2.1 to $3.6 \%$ and was significantly higher in fish fed the HF diets than in those fed the LF ones (Table 4).

Senegalese sole muscle, liver and viscera lipid content are reported in Table 4. Skin and intestine were the preferential tissues for lipid deposition. Dietary lipid level significantly affected viscera and skin, but not muscle or liver lipid 
Table 2. Effect of different dietary lipids in Senegalese sole (Solea senegalensis) growth and intake after $112 \mathrm{~d}$ (Mean values and standard deviations ( $n$ 3))

\begin{tabular}{|c|c|c|c|c|c|c|c|c|c|c|}
\hline \multirow[t]{2}{*}{ Diet... } & \multicolumn{2}{|c|}{ L4 } & \multicolumn{2}{|c|}{ L8 } & \multicolumn{2}{|c|}{ L12 } & \multicolumn{2}{|c|}{ L16 } & \multicolumn{2}{|c|}{ L20 } \\
\hline & Mean & SD & Mean & SD & Mean & SD & Mean & SD & Mean & SD \\
\hline \multicolumn{11}{|l|}{ Growth } \\
\hline Initial body weight (g) & 9.89 & 0.01 & 9.96 & 0.06 & 9.97 & 0.02 & 9.91 & 0.03 & 9.92 & 0.06 \\
\hline Final body weight $(\mathrm{g})$ & $43 \cdot 66^{a}$ & 6.54 & $42.54^{\mathrm{a}}$ & 1.51 & $33.02^{b}$ & 0.56 & $32.57^{\mathrm{b}}$ & $2 \cdot 61$ & $28.54^{\mathrm{b}}$ & 2.56 \\
\hline $\mathrm{DGI}^{*}$ & $1 \cdot 22^{\mathrm{a}}$ & $0 \cdot 16$ & $1 \cdot 20^{\mathrm{a}}$ & 0.03 & $0.94^{\mathrm{b}}$ & 0.02 & $0.93^{\mathrm{b}}$ & 0.07 & $0.81^{\mathrm{b}}$ & 0.08 \\
\hline FCR $†$ & $1.04^{\mathrm{c}}$ & 0.05 & $1.15^{\mathrm{c}}$ & 0.03 & $1.66^{\mathrm{b}}$ & 0.09 & $1.68^{\mathrm{b}}$ & 0.06 & $2 \cdot 16^{\mathrm{a}}$ & 0.18 \\
\hline PER $\ddagger$ & $1.70^{\mathrm{a}}$ & 0.08 & $1.56^{\mathrm{a}}$ & 0.04 & $1.06^{\mathrm{b}}$ & 0.06 & $1.04^{\mathrm{b}}$ & 0.04 & $0.83^{\mathrm{c}}$ & 0.07 \\
\hline \multicolumn{11}{|l|}{ Intake§ } \\
\hline $\mathrm{DM}(\mathrm{g} / \mathrm{kg} \mathrm{ABW}$ per $\mathrm{d})$ & $11.58^{\mathrm{C}}$ & 0.30 & $12 \cdot 70^{\mathrm{C}}$ & 0.42 & $15 \cdot 86^{b}$ & 1.06 & $15 \cdot 96^{\mathrm{b}}$ & 0.43 & $18 \cdot 53^{\mathrm{a}}$ & 0.64 \\
\hline Protein ( $/ / \mathrm{kg}$ ABW per d) & $6 \cdot 61^{\mathrm{C}}$ & 0.17 & $7 \cdot 12^{\mathrm{C}}$ & 0.24 & $9 \cdot 01^{b}$ & 0.60 & $9 \cdot 18^{\mathrm{b}}$ & 0.25 & $10 \cdot 39^{a}$ & 0.36 \\
\hline Lipids (g/kg ABW per d) & $0.47^{\mathrm{e}}$ & 0.01 & $1.07^{\mathrm{d}}$ & 0.04 & $2 \cdot 17^{\mathrm{c}}$ & 0.14 & $2 \cdot 77^{\mathrm{b}}$ & 0.07 & $4 \cdot 17^{\mathrm{a}}$ & 0.14 \\
\hline Energy $(\mathrm{kJ} / \mathrm{kg}$ ABW per d) & $2 \cdot 38^{\mathrm{C}}$ & 0.06 & $2 \cdot 77^{\mathrm{C}}$ & 0.09 & $3.63^{\mathrm{b}}$ & 0.24 & $3.80^{\mathrm{b}}$ & $0 \cdot 10$ & $4.55^{a}$ & 0.15 \\
\hline
\end{tabular}

DGI, daily growth index; FCR, feed conversion ratio; PER, protein efficiency ratio; ABW, average body weight.

${ }^{a-e}$ Mean values within a row with unlike superscript letters were significantly different $(P<0.05)$.

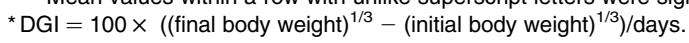

†FCR $=$ dry feed intake/weight gain.

$\ddagger \mathrm{PER}=$ weight gain/crude protein intake.

$\S$ Nutrient intake $=$ nutrient intake/average body weight $(($ initial body weight + final body weight)/2)/days.

contents. Viscera fat content ranged from 3.3 to $7.7 \%$ wet weight whereas skin fat values varied from 1.7 to $2.3 \%$ wet weight, and significant differences were observed among treatments. Fish fed the L16 and L20 diets presented significantly higher viscera and skin lipid contents than those fed with L4. Although muscle total lipids did not vary among dietary treatments, the muscle of fish fed the L4 diet exhibited significantly higher percentages of SFA when compared with the muscle of fish fed the other diets (26v. about $23-24 \%)$. A totally different trend was observed in MUFA, with values ranging from 22 to $29 \%$, and L12 exhibiting the highest content. Moreover, neither PUFA nor DHA:EPA and EPA:arachidonic acid ratios were affected by the dietary lipid levels, whereas $n-3$ fatty acids were highest in fish fed L20.

\section{Discussion}

At the end of the growth trial, final body weight was about triplicate in all treatments, and dietary lipid levels higher than $8 \%$ were shown to significantly depress growth performance

Table 3. Whole-body composition, nutrient retention and gain of Senegalese sole (Solea senegalensis) fed increasing dietary lipid levels for $112 \mathrm{~d}^{*}$

(Mean values and standard deviations $(n 3))$

\begin{tabular}{|c|c|c|c|c|c|c|c|c|c|c|}
\hline \multirow[t]{2}{*}{ Dietary treatment. . } & \multicolumn{2}{|c|}{ L4 } & \multicolumn{2}{|c|}{ L8 } & \multicolumn{2}{|c|}{ L12 } & \multicolumn{2}{|c|}{ L16 } & \multicolumn{2}{|c|}{ L20 } \\
\hline & Mean & SD & Mean & SD & Mean & SD & Mean & SD & Mean & SD \\
\hline \multicolumn{11}{|l|}{ Whole-body composition } \\
\hline Moisture (\% wet weight) & 76.43 & 0.80 & 75.07 & 1.28 & $76 \cdot 25$ & 0.63 & 76.56 & 0.66 & 75.65 & 0.27 \\
\hline Ash (\% wet weight) & 1.79 & 0.19 & 1.73 & 0.27 & 1.89 & 0.41 & 1.63 & 0.16 & 1.59 & 0.08 \\
\hline Protein (\% wet weight) & $17 \cdot 69^{a, b}$ & 0.35 & $18 \cdot 24^{\mathrm{a}}$ & 1.04 & $16 \cdot 93^{\mathrm{a}, \mathrm{b}}$ & 0.47 & $15 \cdot 98^{b}$ & 0.54 & $16 \cdot 18^{b}$ & 0.42 \\
\hline Lipids (\% wet weight) & $3 \cdot 72^{\mathrm{b}}$ & 0.22 & $5 \cdot 02^{\mathrm{a}, \mathrm{b}}$ & 0.44 & $5 \cdot 14^{\mathrm{a}, \mathrm{b}}$ & $0 \cdot 10$ & $5 \cdot 69^{a}$ & 0.84 & $5 \cdot 84^{a}$ & 0.66 \\
\hline Energy (kJ/g wet weight) & $5 \cdot 61$ & 0.13 & $6 \cdot 17$ & 0.33 & $5 \cdot 82$ & 0.03 & 5.85 & 0.38 & 5.98 & 0.11 \\
\hline \multicolumn{11}{|l|}{ Retention ( $\%$ feed intake) $\dagger$} \\
\hline $\mathrm{DM}$ & $22 \cdot 57^{\mathrm{a}}$ & 0.12 & $21.92^{\mathrm{a}}$ & 1.36 & $14 \cdot 19^{b}$ & 0.21 & $13 \cdot 71^{\mathrm{b}}$ & 0.63 & $11 \cdot 34^{\mathrm{b}}$ & $1 \cdot 12$ \\
\hline Protein & $30 \cdot 23^{\mathrm{a}}$ & 0.61 & $28 \cdot 89^{\mathrm{a}}$ & 2.07 & $17 \cdot 87^{b}$ & 0.25 & $15 \cdot 97^{\mathrm{b}, \mathrm{c}}$ & 0.42 & $12 \cdot 99^{\mathrm{c}}$ & 1.63 \\
\hline Lipids & $82.47^{\mathrm{a}}$ & 1.84 & $53.57^{\mathrm{b}}$ & 4.67 & $23 \cdot 9^{\mathrm{c}}$ & 1.95 & $21 \cdot 24^{\mathrm{C}}$ & $4 \cdot 19$ & $13 \cdot 47^{\mathrm{c}}$ & 1.8 \\
\hline Energy & $26 \cdot 14^{\mathrm{a}}$ & 0.50 & $25 \cdot 14^{\mathrm{a}}$ & 1.43 & $15 \cdot 39^{b}$ & 0.72 & $14 \cdot 65^{\mathrm{b}, \mathrm{c}}$ & 1.32 & $11.50^{\mathrm{c}}$ & 1.04 \\
\hline \multicolumn{11}{|l|}{ Gain $\ddagger$} \\
\hline $\mathrm{DM}$ (g/kg ABW per d) & $2 \cdot 61^{a, b}$ & 0.08 & $2 \cdot 78^{a}$ & 0.16 & $2 \cdot 25^{\mathrm{b}, \mathrm{c}}$ & 0.12 & $2 \cdot 19^{b, c}$ & 0.16 & $2 \cdot 10^{c}$ & 0.18 \\
\hline Protein (g/kg ABW per d) & $2 \cdot 00^{\mathrm{a}}$ & 0.09 & $2 \cdot 06^{\mathrm{a}}$ & 0.13 & $1.61^{\mathrm{b}}$ & 0.08 & $1.47^{\mathrm{b}}$ & 0.07 & $1 \cdot 35^{\mathrm{b}}$ & 0.15 \\
\hline Lipids ( $g / \mathrm{kg}$ ABW per d) & 0.39 & 0.001 & 0.57 & 0.07 & 0.52 & 0.01 & 0.59 & 0.13 & 0.56 & 0.09 \\
\hline Energy (kJ/kg ABW per d) & $0.62^{a, b}$ & 0.03 & $0.70^{a}$ & 0.05 & $0.56^{a, b}$ & 0.01 & $0.56^{a, b}$ & 0.06 & $0.52^{\mathrm{b}}$ & 0.05 \\
\hline
\end{tabular}

ABW, average body weight.

a,b,c Mean values within a row with unlike superscript letters were significantly different $(P<0.05)$

*Initial body composition was: moisture, $75.65 \%$ wet weight; ash, $2.49 \%$ wet weight; protein, $17.22 \%$ wet weight; lipids, $4.53 \%$ wet weight; energy, $5.81 \mathrm{~kJ} / \mathrm{g}$ wet weight.

$\dagger$ Retention $=100 \times($ final body weight $\times$ final carcass nutrient content - initial body weight $\times$ initial carcass nutrient content)/nutrient intake

$\ddagger$ Nutrient gain $=$ (nutrient in final carcass - nutrient in initial carcass)/average body weight/days. 
Table 4. Somatic indexes (\%), tissue total lipids and muscle fatty acids classes of Senegalese sole (Solea senegalensis) fed increasing dietary lipid levels for $112 \mathrm{~d}$

(Mean values and standard deviations ( $n 6$, except for somatic indexes, where $n 9)$ )

\begin{tabular}{|c|c|c|c|c|c|c|c|c|c|c|}
\hline \multirow[t]{2}{*}{ Dietary treatment... } & \multicolumn{2}{|c|}{ L4 } & \multicolumn{2}{|c|}{ L8 } & \multicolumn{2}{|c|}{ L12 } & \multicolumn{2}{|c|}{ L16 } & \multicolumn{2}{|c|}{ L20 } \\
\hline & Mean & SD & Mean & SD & Mean & SD & Mean & SD & Mean & SD \\
\hline $\mathrm{HSI}^{*}$ & $0.83^{a, b}$ & 0.22 & $0.73^{b}$ & $0 \cdot 16$ & $0.73^{b}$ & $0 \cdot 10$ & $1.00^{\mathrm{a}}$ & 0.29 & $0.86^{a, b}$ & 0.12 \\
\hline vSI† & $1.98^{\mathrm{b}}$ & 0.41 & $2 \cdot 11^{\mathrm{b}}$ & 0.31 & $2 \cdot 10^{\mathrm{b}}$ & 0.31 & $3 \cdot 60^{\mathrm{a}}$ & 1.41 & $3.04^{\mathrm{a}}$ & 0.39 \\
\hline \multicolumn{11}{|c|}{ Tissue total lipids (\% wet weight) } \\
\hline Liver & 9.38 & $2 \cdot 14$ & $8 \cdot 81$ & 0.98 & 8.02 & 1.98 & $10 \cdot 10$ & 1.81 & 9.09 & $1 \cdot 26$ \\
\hline Viscera & $3.33^{\mathrm{b}}$ & 0.39 & $3 \cdot 17^{b}$ & 0.17 & $3.96^{a, b}$ & 0.78 & $6 \cdot 07^{\mathrm{a}}$ & 1.35 & $7 \cdot 68^{\mathrm{a}}$ & 1.02 \\
\hline Skin & $1.72^{\mathrm{b}}$ & 0.21 & $2 \cdot 16^{a, b}$ & 0.26 & $2 \cdot 15^{a, b}$ & 0.39 & $2 \cdot 33^{a}$ & 0.41 & $2 \cdot 24^{a}$ & 0.18 \\
\hline Muscle & 2.06 & 0.50 & 2.74 & 1.24 & 3.05 & 1.38 & $2 \cdot 20$ & 0.63 & 2.35 & 0.54 \\
\hline \multicolumn{11}{|c|}{ Muscle fatty acid composition ( $\mathrm{g} / 100 \mathrm{~g}$ fatty acids) } \\
\hline$\Sigma$ SFA $\neq$ & $26 \cdot 09^{a}$ & 0.76 & $23 \cdot 82^{b}$ & 1.78 & $23 \cdot 53^{b}$ & 0.42 & $24 \cdot 13^{b}$ & 0.71 & $23 \cdot 14^{\mathrm{b}}$ & 0.95 \\
\hline$\Sigma$ MUFA§ & $22 \cdot 17^{\mathrm{b}}$ & $2 \cdot 63$ & $26 \cdot 57^{\mathrm{a}}$ & 2.94 & $29 \cdot 37^{\mathrm{a}}$ & $2 \cdot 81$ & $26 \cdot 93^{\mathrm{a}}$ & 1.48 & $27 \cdot 67^{\mathrm{a}}$ & 1.65 \\
\hline$\Sigma$ PUFA\| & $41 \cdot 39$ & 1.58 & 38.97 & $2 \cdot 47$ & $38 \cdot 62$ & 1.81 & $39 \cdot 30$ & 1.04 & 39.58 & 0.96 \\
\hline$\sum n-39$ & $25 \cdot 66^{\mathrm{b}}$ & 1.84 & $26 \cdot 01^{\mathrm{b}}$ & 2.02 & $26 \cdot 08^{\mathrm{b}}$ & $2 \cdot 11$ & $28 \cdot 14^{a, b}$ & 1.52 & $29 \cdot 31^{\mathrm{a}}$ & 1.39 \\
\hline DHA:EPA & $4 \cdot 60$ & 0.73 & $4 \cdot 22$ & 0.82 & 3.52 & 0.61 & 4.54 & 0.56 & $4 \cdot 23$ & 0.54 \\
\hline EPA:ARA & $4 \cdot 10$ & $1 \cdot 33$ & 4.08 & 0.68 & $5 \cdot 67$ & 1.29 & 3.78 & 0.69 & $4 \cdot 31$ & 1.37 \\
\hline
\end{tabular}

HSI, hepatosomatic index; VSI, viscerosomatic index; ARA, arachidonic acid.

a,b Mean values within a row with unlike superscript letters were significantly different $(P<0.05)$

${ }^{\star} \mathrm{HSI}=100 \times$ (liver weight/body weight) $(\%)$.

$\dagger \mathrm{VSI}=100 \times($ viscera weight/body weight) $(\%)$.

$\ddagger \Sigma$ SFA $=$ sum of $12: 0,14: 0,15: 0,16: 0,17: 0,18: 0,20: 0,22: 0$ and $24: 0$.

$\S \Sigma$ MUFA $=$ sum of $16: 1,18: 1,20: 1$ and $22: 1$.

$\| \Sigma$ PUFA $=$ sum of $18: 2 n-6,18: 3 n-6,18: 3 n-3,20: 2 n-6,20: 3 n-3,20: 4 n-6,20: 5 n-3,22: 4 n-6,22: 5 n-3$ and $22: 6 n-3$.

I $\Sigma n-3=$ sum of $18: 3 n-3,20: 3 n-3,20: 5 n-3,22: 5 n-3$ and $22: 6 n-3$.

(final body weight and daily growth index). In spite of the dietary protein fraction being achieved by means of a variable blend of practical ingredients such as fishmeal, soyabean meal, maize gluten and wheat gluten, the higher inclusion of vegetable protein sources in the LF diets improved growth and nutrient retention, suggesting a good acceptance of plant sources by solea juveniles. Therefore, the observed differences in growth performance among treatments seem to be mainly due to the dietary lipid levels. This is in agreement with previous studies in turbot that reported a decline in growth rate with diets containing increasing dietary fat levels either in juvenile $^{(17)}$ or commercial-sized fish ${ }^{(18)}$. A growth depression was also observed when halibut juveniles were fed a diet containing $30 \%$ lipid and a low level of carbohydrates ${ }^{(15)}$. Nevertheless, increasing dietary fat levels from $11 \%$ to $21 \%$ in Senegalese sole juveniles during $90 \mathrm{~d}^{(4)}$ or from 8 to $28 \%$ in different Atlantic halibut size classes did not seem to affect growth performance $e^{(12-14,16,24)}$. Unlike salmonids or marine fish species where a protein-sparing effect has been clearly demonstrated $^{(6-8,10,25)}$, no beneficial effects on overall growth performance were observed in Senegalese sole juveniles fed high dietary lipid levels.

The high nutrient intake $(12-19 \mathrm{~g} / \mathrm{kg}$ average body weight per d) and low feed conversion ratio (1-2) values observed in this trial reflect the good acceptability of the diets by sole. Dias et al. ${ }^{(4)}$ reported similar growth performance of Senegalese sole juveniles fed either 11 or $21 \%$ lipids for $90 \mathrm{~d}$, although the registered feed conversion ratio (2.4-3) was clearly inferior to that observed in the present stsudy. The $11 \%$ fat included in those diets did not induce significant differences among dietary treatments, although a slight decrease in weight gain was also noticed in fish fed $21 \%$ lipids. This trend could have resulted in significant differences among dietary treatments if a longer trial duration had been carried out. The high feed conversion ratio values could be related to distinct feeding protocols. In its natural habitat sole remains inactive and buried in the sand the whole day, and carries out all its activity, particularly feeding, during the night ${ }^{(26)}$. Hence, instead of feeding animals $18 \mathrm{~h}$ per $\mathrm{d}$ as adopted by Dias et al. ${ }^{(4)}$ it seems advisable to feed fish $24 \mathrm{~h}$ per $\mathrm{d}$ to achieve maximal growth performance and improve feed conversion. In the present trial, the dietary lipid levels strongly affected both intake and nutrient utilisation, the LF diets being the most efficient in displaying the lowest nutrient intake but best feed conversion ratio and protein efficiency ratio. In fact, the increase in the input of non-protein energy substrates has a deleterious effect on fish growth performance which seems to be related to their poor utilisation by Senegalese sole.

Senegalese sole is considered a lean fish with low whole-body fat contents $(<6 \%)^{(4,5)}$. In the present study whole-body lipid content varied from 4 to $6 \%$, with the L4 diet inducing significantly lower whole-body fat content than L16 and L20 diets. Similarly, in turbot such an effect has been observed when dietary fat levels increased from 10 to $25 \%^{(17)}$. Dias et al. ${ }^{(4)}$ has also reported an increased fat content in sole fed HF diets (10 v. $21 \%)$, but only when associated with low-digestible carbohydrates. Increased whole-body fat content due to an increase in dietary fat has been widely reported in salmonids ${ }^{(8)}$, or other marine teleosts, such as seabass ${ }^{(27)}$, gilthead sea bream ${ }^{(28)}$ or Atlantic halibut $^{(12,13,16)}$, although all these species display significantly higher whole-body fat contents compared with sole. Increasing dietary lipid levels in Senegalese sole resulted in decreased lipid retention, but without any significant effects on fat gain. On the other hand, both protein gain and retention 
were improved by the decrease in dietary lipid. In contrast, Dias et al. ${ }^{(4)}$ observed that Senegalese sole fed diets with $20 \%$ dietary lipids showed similar protein gain but a significantly higher fat gain $(P<0.05)$ when compared with fish fed diets with $10 \%$ lipids. Similarly, in other flatfishes such as turbot ${ }^{(18)}$ and Atlantic halibut ${ }^{(16)}$, protein utilisation was not improved by an increase in dietary lipids. However, other studies with Atlantic halibut reported a protein-sparing effect with increasing dietary lipids ${ }^{(12,24)}$, though the diets were not isonitrogenous. In species such as salmon ${ }^{(8)}$, trout $^{(10)}$, gilthead seabream ${ }^{(28)}$ and European seabass ${ }^{(25)}$, protein retention may be improved by partly replacing dietary protein by lipids, but in flatfish species this protein sparing seems to be controversial. In Senegalese sole such a wide dietary lipid range (4-20\%) has never been evaluated before, but the obtained results suggest a poor utilisation of the lipid fraction that warrants further investigation. The determination of nutrients' apparent digestibility coefficients could help clarifying this point. Several attempts for faeces collection have been carried out; nevertheless neither decantation methods nor fish stripping have been proven to be feasible for this species, due to the physical properties of the faeces and the morphology of the intestine. The dissection of the intestine seems to be the only way to recuperate faeces, but a great number of juveniles or larger-sized fish are required. Moreover, in the present study, the lack of a protein-sparing effect by dietary lipid might also be related to the high protein level of the experimental diets. Dias et al. ${ }^{(25)}$ reported that, in sea bass, an increase in lipid level from 10 to $18 \%$ only was beneficial at low protein levels $(40 \%)$. This suggests the need to optimise the dietary protein:lipid ratio to the metabolic needs of Senegalese sole juveniles.

Liver lipid content ranged from 8.0 to $10.1 \%$ of liver wet weight, and was unaffected by dietary lipid level. Overall, liver lipids contribute to $0.1 \%$ of final body weight and $1.7 \%$ of total lipid content. Higher liver lipid contents were reported by Dias et al. ${ }^{(4)}$ in this species and in species such as turbot ${ }^{(18)}$ and Atlantic halibut ${ }^{(16)}$. Moreover, Dias et al. ${ }^{(4)}$ observed that elevated levels of dietary lipids in Senegalese sole increased liver lipid content and depressed the lipogenic enzymic activity. Different results were reported in turbot, where the absence of any change in hepatic lipogenic enzymes was associated with a low lipid deposition and relative absence of response to high dietary lipid levels. In the present study, significant differences were found for hepatosomatic index among dietary treatments, but there was no clear association with dietary lipid level since L4 and L20 were similar. Hepatosomatic index values reported are in accordance with those found by Dias et al. ${ }^{(4)}$ in Senegalese sole but lower than other flatfish species such as turbot ${ }^{(18)}$ and Atlantic halibut $^{(12,16,24)}$ and other marine teleosts such as European seabass $^{(25)}$ and gilthead seabream ${ }^{(29)}$.

Both the viscerosomatic index and viscera total lipids of Senegalese sole increased with dietary lipid levels but were generally lower than values previously found in other teleosts including flatfish species ${ }^{(4,18,29,30)}$. Lipid content of the viscera represents $0 \cdot 1-0 \cdot 2 \%$ of body weight and $4 \%$ of the wholebody lipids. Despite the higher values observed in other marine species, it is clear that Senegalese sole tends to accumulate part of the fat in the viscera. Moreover, fish fed HF diets exhibit a significantly higher viscerosomatic index, essentially due to increased fat deposition in the viscera. This is in general accord with earlier observations by Aksnes et al. ${ }^{(12)}$ that reported similar results in halibut with increasing dietary lipids. Nevertheless, lower values of fat in the viscera $(0 \cdot 2-0.8 \%)$ were previously reported in Senegalese sole $\mathrm{e}^{(4)}$ and could not induce viscerosomatic index differences among treatments. In halibut, it was observed that a high dietary lipid level (13 to $32 \%$ ) decreased slaughter quality ${ }^{(12)}$, but that was not found in turbot ${ }^{(18)}$. In the present study, viscera total lipids decreased with the LF diets, contributing to a significant decrease of whole-body lipid composition but an increase in the protein content. These results suggest a poor utilisation of dietary lipids and the potential value of such LF diets in improving Senegalese sole growth potential.

The content of total lipids of dorsal muscle ranged from $2 \cdot 1$ to $3.1 \%$ on a fresh-weight basis, representing $1.3 \%$ of wholebody weight and $27 \%$ of total whole-body lipids. Nevertheless, contrarily to the viscera, muscle total lipids were not affected by increasing dietary lipid levels. These results are in agreement with earlier observations in flatfish species such as halibut ${ }^{(13,16)}$, turbot ${ }^{(18)}$ and Senegalese sole ${ }^{(4)}$, and suggest that other tissues such as skin and subdermal adipose tissue or other carcass fraction (fins, brain, bones) might be important fat-storage sites. In the present study, Senegalese sole subdermal fat only represented about $0.2 \%$ of wholebody weight and $4 \%$ of total body lipids, showing that lipids are probably being accumulated under the skin like in turbot $^{(18)}$ and between the dorsal and ventral fins and around the belly flap like in halibut ${ }^{(31)}$.

Besides being energy-providing nutrients, dietary lipids are important in marine fish as a source of essential fatty acids, especially 20:5n-3 (EPA), 2220:6n-3 (DHA) and 2020:4n-6 (arachidonic acid) $^{(32)}$. The fatty acid compositions of tissue lipids in fish are well known to be influenced by the fatty acid composition of dietary lipids ${ }^{(32)}$. This was the case in the present study, where a linear correlation existed between the concentrations of given fatty acids in dietary lipids and their concentrations in flesh total lipids. Taking into account that no significant differences were found in muscle total lipids among dietary treatments, fish fed the L4 diet effectively contained lower levels of $n-3$ fatty acids if compared with L20fed ones. Additionally, the L4 diet induced a lower MUFA content, probably leading to the mobilisation of the $n$ - 3 fatty acids for energetic proposes. Nevertheless, the L20 diet reduced growth and did not improve nutrient utilisation in this species and hence does not seem to be suitable for Senegalese sole juveniles. Despite the slight alteration in $n-3$ muscle content in the fish fed the LF diets, this fish still remains an $n$-3-rich product contributing to the human health benefits associated with fish consumption, especially regarding DHA and $\mathrm{EPA}^{(33,34)}$. In fact, even at dietary lipid levels as low as $4 \%$, Senegalese sole DHA:EPA and EPA:arachidonic acid ratios remained unchanged and hence muscle maintained its nutritional value. Moreover, in southern European countries this fish is generally consumed grilled without removing the skin. As the skin is one of the preferential organs for fat deposition in flatfish, it could be suspected that some lipid migration of the fat deposited in the subdermal adipose tissue could occur during the cooking process, increasing even further the nutritional value of the flesh.

In conclusion, the results of the present study evidenced a low lipid tolerance by Senegalese sole juveniles and suggest 
a maximal dietary inclusion level of $8 \%$ lipids for both optimal growth and nutrient utilisation. Future studies are required to ascertain whether the absence of a clear protein-sparing effect by dietary lipids holds up at lower dietary protein levels or in large-sized fish. Concerning the lipid metabolism of this flatfish, it would be worthwhile investigating which are the mechanisms responsible for the apparent poor utilisation of the dietary lipids. A better understanding of the metabolic changes induced by the dietary protein:lipid ratio should allow adjustment of the diet composition to the metabolic capacities of Senegalese sole juveniles.

\section{Acknowledgements}

The present study was supported by IDEIA project 'Optidietas' (Agência de Inovação, Portugal, with the support of the European fund FEDER).

P. B. carried out the main experimental work and wrote the draft under the direction of the project designer and leader L. M. P. V.; B. O., J. D. and L. C. assisted with the experimental design and draft writing; S. C. assisted fatty acid determination and draft writing.

There are no conflicts of interest in connection with the present study.

\section{References}

1. Conceição LEC, Ribeiro L, Engrola S, et al. (2007) Nutritional physiology during development of Senegalese sole (Solea senegalensis). Aquaculture 268, 64-81.

2. Imsland A, Foss A, Conceição L, et al. (2003) A review of the culture potential of Solea solea and S. senegalensis. Rev Fish Biol Fish 13, 379-407.

3. Villalta M, Estévez A, Bransden MP, et al. (2008) Arachidonic acid, arachidonic/eicosapentaenoic acid ratio, stearidonic acid and eicosanoids are involved in dietary-induced albinism in Senegal sole (Solea senegalensis). Aquac Nutr 14, 120-128.

4. Dias J, Rueda-Jasso R, Panserat S, et al. (2004) Effect of dietary carbohydrate-to-lipid ratios on growth, lipid deposition and metabolic hepatic enzymes in juvenile Senegalese sole (Solea senegalensis, Kaup). Aquac Res 35, 1122-1130.

5. Rema P, Conceição LEC, Evers F, et al. (2008) Optimal dietary protein levels in juvenile Senegalese sole (Solea senegalensis). Aquac Nutr 14, 263-269.

6. Cho CY, Hynes JD, Wood KR, et al. (1994) Development of high-nutrient-dense, low-pollution diets and prediction of aquaculture wastes using biological approaches. Aquaculture 124, 293-305.

7. Company R, Calduch-Giner JA, Perez-Sanchez J, et al. (1999) Protein sparing effect of dietary lipids in common dentex (Dentex dentex): a comparative study with sea bream (Sparus aurata) and sea bass (Dicentrarchus labrax). Aquat Living Resour 12, 23-30.

8. Hillestad M \& Johnsen F (1994) High-energy/low-protein diets for Atlantic salmon: effects on growth, nutrient retention and slaughter quality. Aquaculture 124, 109.

9. Kaushik SJ (1998) Nutritional bioenergetics and estimation of waste production in non-salmonids. Aquat Living Resour 11, 211-217.

10. Lee DJ \& Putnam GB (1973) The response of rainbow trout to varying protein/energy ratios in a test diet. J Nutr 103, 916-922.
11. Cowey CB, Adron JW, Brown DA, et al. (1975) Studies on nutrition of marine flatfish - metabolism of glucose by plaice (Pleuronectes platessa) and effect of dietary energy-source on protein utilization in plaice. Br J Nutr 33, 219-231.

12. Aksnes A, Hjertnes T \& Opstvedt J (1996) Effect of dietary protein level on growth and carcass composition in Atlantic halibut (Hippoglossus hippoglossus L). Aquaculture 145, 225-233.

13. Berge GM \& Storebakken T (1991) Effect of dietary fat level on weight gain, digestibility, and fillet composition of Atlantic halibut. Aquaculture 99, 331-338.

14. Grisdale-Helland B \& Helland SJ (1998) Macronutrient utilization by Atlantic halibut (Hippoglossus hippoglossus): diet digestibility and growth of $1 \mathrm{~kg}$ fish. Aquaculture 166, 57-65.

15. Hamre K, Øfsti A, Næss T, et al. (2003) Macronutrient composition of formulated diets for Atlantic halibut (Hippoglossus hippoglossus, L.) juveniles. Aquaculture 227, 233-244.

16. Martins DA, Valente LMP \& Lall SP (2007) Effects of dietary lipid level on growth and lipid utilization by juvenile Atlantic halibut (Hippoglossus hippoglossus, L.). Aquaculture 263, $150-158$

17. Caceres-Martinez C, Cadena-Roa M \& Metailler R (1984) Nutritional requirements of turbot (Scophthalmus maximus): I. A preliminary study of protein and lipid utilization. $J$ World Maricult Soc 15, 191-202.

18. Regost C, Arzel J, Cardinal M, et al. (2001) Dietary lipid level, hepatic lipogenesis and flesh quality in turbot (Psetta maxima). Aquaculture 193, 291-309.

19. Corraze G (2001) Lipid nutrition. In Nutrition and Feeding of Fish and Crustaceans, pp. 111-130 [J Guillaume, S Kaushik and $\mathrm{K}$ Métailler et al., editors]. Chichester, UK: Springer Praxis.

20. Andersen NG \& Alsted NS (1993) Growth and body composition of turbot (Scopthalmus maximus) in relation to different lipid/protein ratios in the diet. In Fish Nutrition in Practice, pp. 479-491 [SJ Kaushik and P Luquet, editors]. Biarritz, France: INRA.

21. Folch J, Lees M \& Sloane Stanley GH (1957) A simple method for the isolation and purification of total lipides from animal tissues. J Biol Chem 226, 497-509.

22. Shantha NC \& Ackman RG (1990) Nervonic acid versus tricosanoic acid as internal standards in quantitative gas chromatographic analyses of fish oil longer-chain $n-3$ polyunsaturated fatty acid methyl esters. J Chromatogr Biomed Appl 533, $1-10$.

23. Zar JH (1999) Biostatistical Analysis, 4th ed. London: Prentice Hall.

24. Helland SJ \& Grisdale-Helland B (1998) Growth, feed utilization and body composition of juvenile Atlantic halibut (Hippoglossus hippoglossus) fed diets differing in the ratio between the macronutrients. Aquaculture 166, 49-56.

25. Dias J, Alvarez MJ, Diez A, et al. (1998) Regulation of hepatic lipogenesis by dietary protein/energy in juvenile European seabass (Dicentrarchus labrax). Aquaculture 161, 169-186.

26. Kruuk H (1963) Diurnal periodicity in the activity of the common sole, Solea vulgaris. Neth J Sea Res 2, 1-28.

27. Peres H \& Oliva-Teles A (1999) Effect of dietary lipid level on growth performance and feed utilization by European sea bass juveniles (Dicentrarchus labrax). Aquaculture 179, 325-334.

28. Vergara JM, Lopez-Calero G, Robaina L, et al. (1999) Growth, feed utilization and body lipid content of gilthead seabream (Sparus aurata) fed increasing lipid levels and fish meals of different quality. Aquaculture 179, 35.

29. Santinha PJM, Medale G, Corraze EFS, et al. (1999) Effects of the dietary protein: lipid ratio on growth and nutrient utilization in gilthead seabream (Sparus aurata L.). Aquac Nutr 5, $147-156$. 
30. Oliva-Teles A, Gouveia AJ, Gomes E, et al. (1994) The effect of different processing treatments on soybean meal utilization by rainbow trout, Oncorhynchus mykiss. Aquaculture 124, 343-349.

31. Haug T, Ringo E \& Pettersen GW (1988) Total lipid and fattyacid composition of polar and neutral lipids in different tissues of Atlantic halibut, Hippoglossus-hippoglossus (L). Sarsia 73, $163-168$
32. Sargent JR, Tocher DR, Bell JG, et al. (2002) The lipids. In Fish Nutrition, 3rd ed., pp. 181-257. San Diego: Academic Press.

33. Ruxton CHS, Reed SC, Simpson MJA, et al. (2004) The health benefits of omega- 3 polyunsaturated fatty acids: a review of the evidence. J Hum Nutr Diet 17, 449-459.

34. Simopoulos AP (1999) Essential fatty acids in health and chronic disease. Am J Clin Nutr 3, Suppl., 560S-569S. 